\title{
CATALYTIC ACTIVITY TEST OF NiMo AND MoNi IMPREGNATED ON MESOPOROUS CARBON FROM BOVINE BONE GELATIN FOR HYDROCRACKING OF LUBRICANT WASTE
}

\author{
Farin Windy Artanti ${ }^{1}$, Wega Trisunaryanti ${ }^{1{ }^{*}}$, Marthinus Pongsendana ${ }^{1}$, \\ Triyono $^{1}$, Iip Izul Falah ${ }^{1}$ and Muhammad Fajar Marsuki ${ }^{2}$ \\ ${ }^{1}$ Department of Chemistry, Universitas Gadjah Mada, Yogyakarta, Indonesia \\ ${ }^{2}$ Study Program of Natural Sciences Education, Universitas Negeri Malang, Malang, Indonesia \\ *E-mail: wegats@ugm.ac.id
}

\begin{abstract}
Synthesis of mesoporous carbon (MC) from bovine bone gelatin, NiMo/MC catalyst and MoNi/MC catalyst for hydrocracking of lubricant waste have been conducted. The Gelatin was extracted from bovine bone using $\mathrm{CH}_{3} \mathrm{COOH}, \mathrm{NaOH}$ and $\mathrm{HCl}$. The $\mathrm{MC}$ was synthesized using bovine bone gelatin as a carbon source and SBA-15 as a template. The Ni and Mo metals were loaded onto the MC by wet impregnation method. The MC material was characterized by FTIR spectrometer, TEM, SEM, and SAA. The NiMo/MC and MoNi/MC catalyst were characterized by SEM-EDX and SAA. The acidity of catalysts was determined by a gravimetric method using ammonia base vapor as the adsorbate. The catalytic activity test was conducted on the hydrocracking of lubricant waste. The liquid fraction of the hydrocracking product was analyzed using GC-MS. The research results showed that the MC material has a pore diameter, surface area, total pore volume, and acidity of $7.52 \mathrm{~nm}, 404.47 \mathrm{~m} / \mathrm{g}$, $0.76 \mathrm{~cm}^{3} / \mathrm{g}$, and $5.01 \mathrm{mmol} / \mathrm{g}$, respectively. The highest liquid fraction $(64.15 \%)$ as a hydrocracking product of the lubricant waste was obtained using MoNi/MC catalyst at a lubricant/catalyst weight ratio of 300 which contains gasoline, diesel and heavy oil fraction of 45.58, 9.99 and $0.78 \mathrm{wt} \%$, respectively.
\end{abstract}

Keywords: carbon, catalyst, hydrocracking, lubricant, mesoporous.

(C) RASĀYAN. All rights reserved

\section{INTRODUCTION}

Lubricants have become an important part of human life, especially in the process of vehicle maintenance. The use of lubricants on vehicles is generally used for about a month or after the vehicle is used as far as $2000 \mathrm{~km}$ as recommended by the manufacturer. After that period, the old lubricant must be replaced with a new lubricant. However, this old lubricant or lubricant waste is only used as a motor chain lubricant or other goods. Whereas this lubricant waste consists of hydrocarbon compounds that can be utilized as a fuel source ${ }^{1,2}$.

Lubricant waste, of course, can not be used directly as fuel. This is because lubricant waste contains heteroatom poly aromatic compounds ${ }^{3}$. For that, this lubricant must be processed to purify its contents. In addition, the lubricant waste contains long-chain hydrocarbon compounds that must be cracked into a fuel fraction. The cracking process requires a transition metal as a catalyst to run efficiently and produce a large number of products ${ }^{4,5}$. Ni and Mo metals have been reported to have good catalytic activity in dehydrosulfuration and hydrocracking processes ${ }^{5-7}$. However, the use of a transition metal as a catalyst directly may lead to unexpected agglomeration and sintering ${ }^{8}$. This problem can be solved by loading the transition metal in a porous support material. The porous support material can increase the surface area of the catalyst so that the active site of the catalyst is greater ${ }^{9}$. Mesoporous carbon as one of the porous support materials can be synthesized from various sources such as sucrose and furfuryl alcohol ${ }^{3,10}$. However, carbon sources such as

Rasayan J. Chem., 11(4), 1433-1440(2018)

http://dx.doi.org/10.31788/RJC.2018.1143073

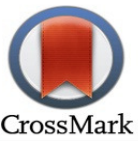


sucrose and furfuryl alcohol are expensive. As an alternative, mesoporous carbon can be synthesized from gelatin $^{11,12}$.

In this study, mesoporous carbon was synthesized using gelatin extracted from cow bone and SBA-15 as a template. The mesoporous carbon is emitted with nickel metal and molybdenum. The activity of the catalyst is evaluated in the hydrocracking process of the lubricant waste.

\section{Material}

\section{EXPERIMENTAL}

Bovine bone was obtained from Yogyakarta, Indonesia. SBA-15 was purchased from Sigma-Aldrich. Hydrochloric acid $(\mathrm{HCl})$, sodium hydroxide $(\mathrm{NaOH})$, acetic acid $\left(\mathrm{CH}_{3} \mathrm{COOH}\right)$, nickel (II) nitrate hexahydrate $\left(\mathrm{Ni}\left(\mathrm{NO}_{3}\right)_{2} \cdot 6 \mathrm{H}_{2} \mathrm{O}\right)$, hydrofluoric acid (HF), sulfuric acid $\left(\mathrm{H}_{2} \mathrm{SO}_{4}\right)$ and ammonium heptamolybdate tetrahydrate $\left(\left(\mathrm{NH}_{4}\right)_{6} \mathrm{Mo}_{7} \mathrm{O}_{24} \cdot 4 \mathrm{H}_{2} \mathrm{O}\right)$ were purchased from Merck. All of the reagents used were analytical grade and used without further purification.

\section{General Procedure}

\section{Synthesis of Mesoporous Carbon}

The synthesis of mesoporous carbon (MC) was carried out by following Ulfa and her co-worker ${ }^{9}$ procedure with slight modifications. Gelatin, sulfuric acid and aquabidest (1:0.2:100 g) were homogenized. The gelatin solution was dropwise added to $3 \mathrm{~g}$ of SBA-15. The mixture was heated at $100^{\circ} \mathrm{C}$ for $6 \mathrm{~h}$ and 160 ${ }^{\circ} \mathrm{C}$ for $6 \mathrm{~h}$ to produce a brown solid. The brown solid was then carbonized in a furnace at $900{ }^{\circ} \mathrm{C}$ (heating rate of $5^{\circ} \mathrm{C} / \mathrm{min}$ ) for $4 \mathrm{~h}$ under argon gas stream (flow rate of $40 \mathrm{cc} / \mathrm{min}$ ). The solid was stirred with $10 \%$ $\mathrm{HF}$ solution (ethanol-water) for $24 \mathrm{~h}$ at room temperature. The solid was dried at $100{ }^{\circ} \mathrm{C}$ for $24 \mathrm{~h}$ to produce mesoporous carbon (MC). The MC was characterized by FTIR spectrometer, AAS, TEM, and SEM-EDS.

\section{Impregnation of Ni and Mo Metals on Mesoporous Carbon}

Metal impregnation was carried out using a wet impregnation method. Amount of metal used in the impregnation process was about $2 \%$. The Mo metal was firstly loaded followed by Ni metal to produce $\mathrm{NiMo} / \mathrm{MC}$ catalyst and vice versa for $\mathrm{MoNi} / \mathrm{MC}$ catalysts. After the impregnation process, the catalysts were dried at $120^{\circ} \mathrm{C}$ for $12 \mathrm{~h}$. Finally, the catalysts were calcined $400{ }^{\circ} \mathrm{C}$ for $4 \mathrm{~h}$ under nitrogen gas stream (flow rate of $40 \mathrm{cc} / \mathrm{min}$ ) and then reduced at $450{ }^{\circ} \mathrm{C}$ for $3 \mathrm{~h}$ under hydrogen gas stream (flow rate of 20 $\mathrm{cc} / \mathrm{min})$. The catalysts were characterized by AAS and SEM-EDX.

\section{Catalyst Activity Test}

The lubricant waste was hydrocracking at $475^{\circ} \mathrm{C}$ for $1 \mathrm{~h}$ under hydrogen gas stream (flow rate of $20 \mathrm{cc} / \mathrm{min}$ ) in a semi-bacth stainless steel reactor (id: $4.5 \mathrm{~cm}$, od: $4.8 \mathrm{~cm}$, length: $30 \mathrm{~cm}$ ) using the catalysts synthesized in this work. The catalyst/lubricant waste ratio was varied in 1/50, 1/100,1/200,1/300, and 1/500 (w/w). The liquid product obtained from hydrocracking process was analyzed by GC-MS. The hydrocracking product distribution was calculated using the following formula:

$$
\text { Product Distribution }(\%)=\frac{\text { the weight of the product (liquid, coke or residue) }}{\text { the initial weight of lubricant waste }} \times 100 \%
$$

\section{Detection Method}

The functional groups of all sample were determined using Fourier Transform Infrared spectrometer (FTIR, Shimadzu Prestige-21) equipped with data station in the range of $400-400 \mathrm{~cm}^{-1}$ with a $\mathrm{KBr}$ disc technique. Surface Area Analyzer (SAA, Quantachrome NovaWin Series) was used to determine the surface parameters (surface area, pore volume, and pore diameter) of the sample. The determination was based on physical adsorption of $\mathrm{N}_{2}$ gas at a batch temperature of $77.3 \mathrm{~K}$. The sample was degassed at $300{ }^{\circ} \mathrm{C}$ for $3 \mathrm{~h}$. The pore morphology was taken using a Transmission Electron Microscope (TEM, JEOL JEM-1400) at $120 \mathrm{kV}$ accelerating voltage. The metal content of all sample was determined using Electron Dispersion Xray Spectrometer (EDX). Sodium Dodecyl Sulphate-Poly Acrylamide Gel Electrophoresis (SDS-PAGE, ATTO PAGERUN ELMER 3110) was used to determine the molecular weight distribution range of the gelatin. The liquid produced by hydrocracking of lubricant waste was analyzed using gas chromatography- 
mass spectrometry (GC-MS, Shimadzu QP2010S) with a column length of $30 \mathrm{~m}$, the diameter of $0.25 \mathrm{~mm}$, the thickness of $0.25 \mu \mathrm{m}$, the temperature of $60-310{ }^{\circ} \mathrm{C}$, Helium gas as carrier gas, and an acceleration voltage of $70 \mathrm{Ev}$. The acidity test of all samples was carried using the gravimetric method with ammonia vapor as the adsorbate. The sample was placed in a desiccator at a vacuum condition and the ammonia vapor flowed into the desiccator (about $5 \mathrm{~mL}$ of ammonia was evaporated for one sample). The sample was aged in the desiccator for $24 \mathrm{~h}$. The increasing of the weight of the sample was measured to determine the amount of ammonia vapor bound to the sample.

\section{Characterization of Gelatin}

\section{RESULTS AND DISCUSSION}

Figure-1(a) presents FTIR spectra of gelatin extracted from the bovine bone in this work. The absorption bands at $3600-3400 \mathrm{~cm}^{-1}$ indicate the stretching vibration of the $\mathrm{N}-\mathrm{H}$ group. The absorption band that occurs at $1242 \mathrm{~cm}^{-1}$ corresponds to the bending vibration of the $\mathrm{H}-\mathrm{N}-\mathrm{H}$ group. In addition, the $\mathrm{C}=\mathrm{O}$ stretching vibration, which is passed with $\mathrm{N}-\mathrm{H}$ bending vibration, give an absorption band at $1636 \mathrm{~cm}^{-1}$. The stretching vibration of the $\mathrm{O}-\mathrm{H}$ group is confirmed by the appearance of an absorption band at $3094 \mathrm{~cm}^{-1}$. The absorption band at $2924 \mathrm{~cm}^{-1}$ indicates the presence of $\mathrm{C}-\mathrm{H}$ stretching vibration in form of $s p^{3}$. The absorption band that appears at $1543 \mathrm{~cm}^{-1}$ indicates the $\mathrm{CN}$ stretching vibration and $\mathrm{CH}_{2}$ bending vibration. The bending vibration of the $\mathrm{C}=\mathrm{O}$ group in the ring short chain peptides is marked by the appearance of an absorption band at $1165 \mathrm{~cm}^{-1}$. All of these absorption band is characteristic for IR spectra of gelatin ${ }^{13,14}$. It can be concluded that the gelatin was successfully extracted from the bovine bone in this work.

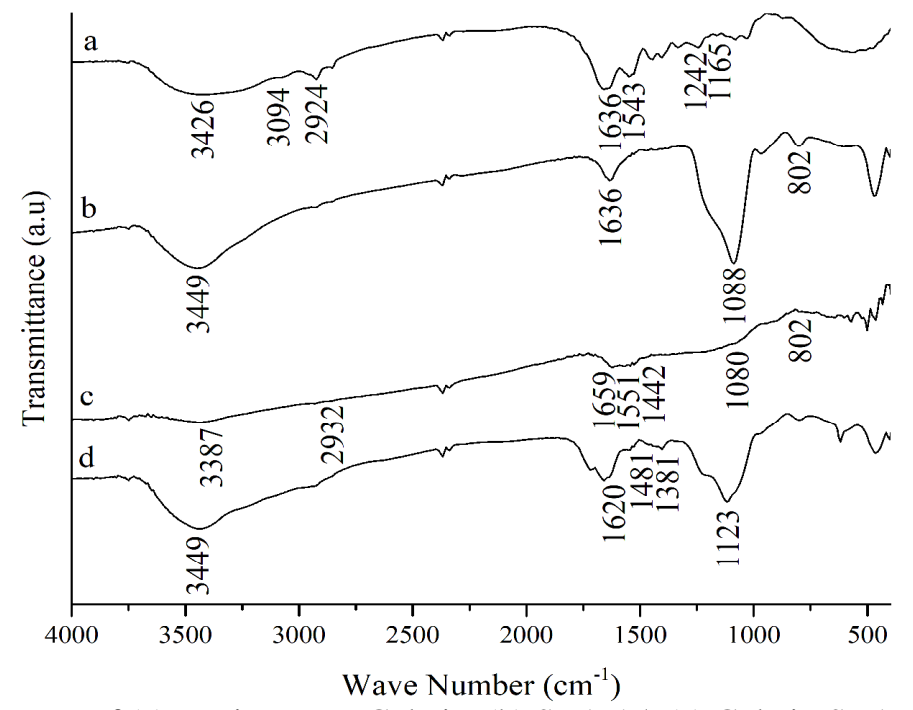

Fig.-1: FTIR Spectra of (a) Bovine Bone Gelatin, (b) SBA-15, (c) Gelatin-SBA-15, and (d) MC

Determination of molecular size of gelatin extracted from bovine bone was carried out using SDS-PAGE and the result is showed in Figure-2. The molecular weight is determined using an equation derived from the standard curve of gelatin. The electroforegram of gelatin has a darker area in the range of $83-170 \mathrm{kDa}$ which means that the gelatin extracted from the bovine bone in this work has a molecular weight distribution range of $83-170 \mathrm{kDa}$. This result indicates that the gelatin can be used as a carbon source because the gelatin component is dominated by $\alpha$ chain collagen. The $\alpha$ chain collagen has many amino groups and plays an important role for binding silanol group of SBA- $15^{3}$.

\section{Characterization of Mesoporous Carbon}

Figure-3 shows TEM micrographs of mesoporous carbon. The pore shape of mesoporous carbon synthesized in this work has a similar structure to SBA-15. It makes senses because the structure of mesoporous carbon looks like a negative replica of the used template (SBA-15) after removal of the template. Mesoporous carbon morphological characters in this study followed the SBA-15 is used as the 
RASĀYAN J. Chem.

Vol. 11 | No. 4 |1433 - 1440| October - December | 2018

template. SEM image shows the topography difference before and after the mesoporous carbon entrusted metals. Figure 4 shows the size of catalyst $\mathrm{MoNi} / \mathrm{MC}$ and NiMo/MC with a uniform particle size of about $1 \mu \mathrm{m}$.

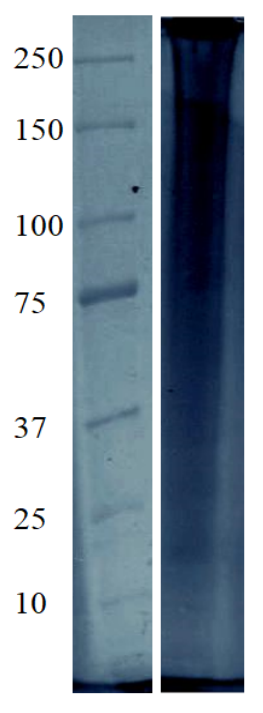

a b

Fig.-2: SDS-PAGE Electroforegram (a) Protein Marker and (b) Bovine Bone Gelatin

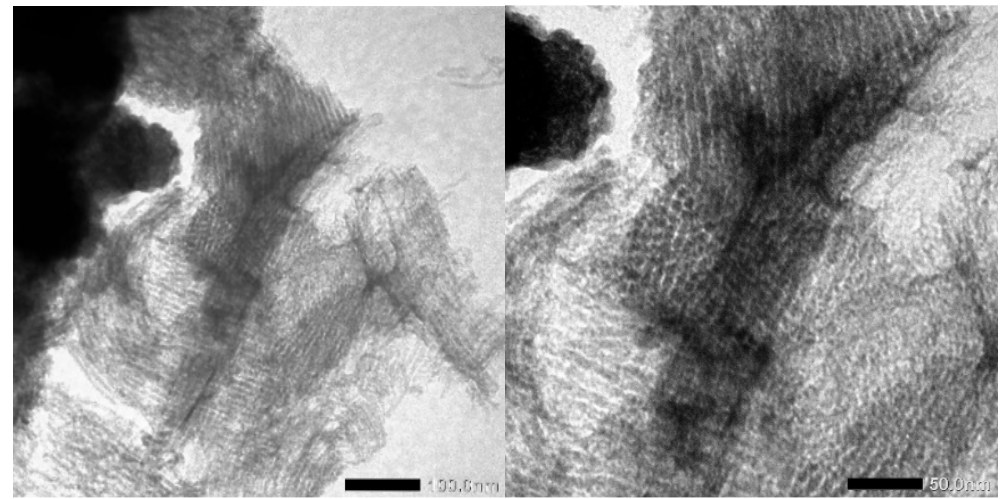

Fig.-3: TEM Image of MC

SEM image of mesoporous carbon and MoNi/MC catalyst is presented in Figure-4. The SEM image of $\mathrm{MoNi} / \mathrm{MC}$ catalyst is brighter than SEM image of MC. The similar result was also reported by other researchers that synthesize mesoporous carbon using SBA-15 as a template ${ }^{3,9,11}$. Mesoporous carbon that has been loaded with transition metals like Mo and Ni has a brighter SEM image. The element which has a higher atomic number will reflect more electrons due to their positive charge on the atomic nucleus, so that the signal emitted back higher.

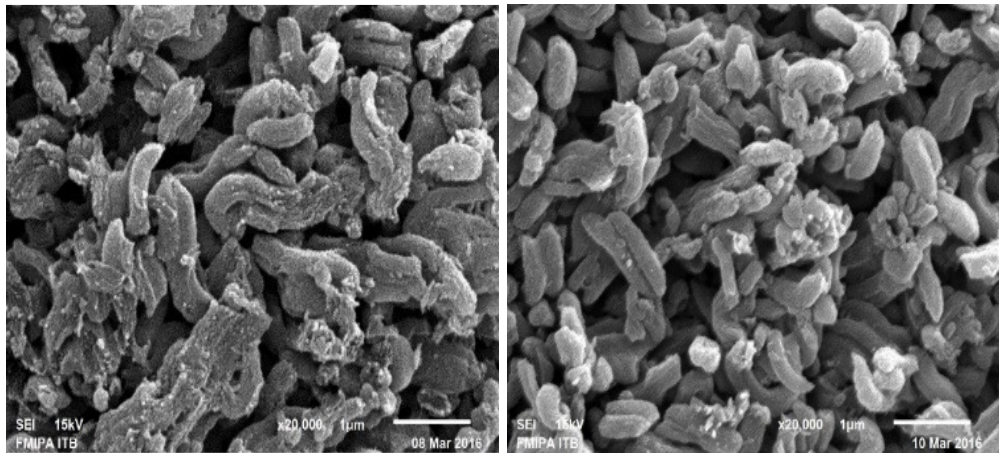

Fig.-4: SEM Image of (a) MC and (b) MoNi/MC Catalysts 
Figure-1 shows the FTIR spectra of each stage of the synthesis process of mesoporous carbon. In Figure1(b), the absorption bands at 1088 and $802 \mathrm{~cm}^{-1}$ is a specific absorption band of the SBA-15 silica matrix and they indicate the asymmetry and symmetry stretching vibration of $\mathrm{Si}-\mathrm{O}-\mathrm{Si}$, respectively ${ }^{3,9}$. Figure-1(c) presents the FTIR spectra of the gelatin-SBA-15 composite before carbonization process and it has absorption bands at $802 \mathrm{~cm}^{-1}$ and $1080 \mathrm{~cm}^{-1}$ from its SBA-15. The FTIR spectra of the gelatin-SBA-15 composite have also an absorption band at $2932 \mathrm{~cm}^{-1}$ which refers to the vibration of an alkyl chain $\left(\mathrm{CH}_{2}\right)$ and it indicates the interaction of silica and amine group of bovine bone gelatin. This interaction of amine groups with silanol is a hydrogen bond.

In other hand, FTIR spectra of mesoporous carbon which is presented in Figure-1(d) has no absorption bands at 1088 and $802 \mathrm{~cm}^{-1}$. It means that the SBA-15 was successfully removed from mesoporous carbon after the leaching process using $\mathrm{HF}$.

The absorption band at $1620 \mathrm{~cm}^{-1}$ in Figure-1(d) corresponds to the vibration of the double bond of the aromatic ring and carboxylate.The absorption band at $1273 \mathrm{~cm}^{-1}$ refers to the vibration of the $\mathrm{C}-\mathrm{O}$ group and it is characteristic for mesoporous carbon. The absorption band at $1362 \mathrm{~cm}^{-1}$ indicates the vibration of a group derived from alcohols, phenols and carboxylic $(\mathrm{COOH})^{15,16}$. The absorption bands that appeared at 1481 and $1620 \mathrm{~cm}^{-1}$ corresponds to the vibration of the $\mathrm{C}=\mathrm{C}$ group in the aromatic ring and $\mathrm{C}=\mathrm{C}$ group, respectively. This result means the mesoporous carbon was successfully synthesized in this work.

Table-1: Metal Content in Catalyst

\begin{tabular}{c|c|c|c}
\hline \multirow{2}{*}{ Catalyst } & \multicolumn{3}{|c}{ Metal content (wt.\%) } \\
\cline { 2 - 4 } & $\mathrm{Ni}$ & $\mathrm{Mo}$ & Total \\
\hline $\mathrm{MC}$ & 0.00 & 0.00 & 0.00 \\
\hline $\mathrm{NiMo} / \mathrm{MC}$ & 0.39 & 1.26 & 1.65 \\
\hline $\mathrm{MoNi} / \mathrm{MC}$ & 0.28 & 1.41 & 1.69 \\
\hline
\end{tabular}

Table-1 shows EDX analysis result of MC and catalysts. The amount of Mo metal in NiMo/MC and $\mathrm{MoNi} / \mathrm{MS}$ catalysts is about $1.26 \mathrm{wt} . \%$. This result is higher than expected. However, the amount of Ni metal in NiMo/MC and MoNi/MC catalysts is lower than expected. This mismatch may be caused by competition of $\mathrm{Ni}$ and Mo metals in pore mouth region ${ }^{6}$. In addition, there was an interaction between saltsolvent which can resist the interaction between salt-MC ${ }^{7}$.

Table-2: Surface Parameters and Acidity Test Result of MC and Catalysts

\begin{tabular}{c|c|c|c|c}
\hline Sample & $\begin{array}{c}\text { Surface Area } \\
\left(\mathrm{m}^{2} / \mathrm{g}\right)\end{array}$ & $\begin{array}{c}\text { Pore Volume } \\
\left(\mathrm{cm}^{3} / \mathrm{g}\right)\end{array}$ & $\begin{array}{c}\text { Pore Diameter } \\
(\mathrm{nm})\end{array}$ & $\begin{array}{c}\text { Acidity Catalyst } \\
(\mathrm{mmol} / \mathrm{g})\end{array}$ \\
\hline $\mathrm{MC}$ & 404,47 & 0,76 & 7,52 & 5,42 \\
\hline $\mathrm{NiMo} / \mathrm{MC}$ & 560,90 & 0,80 & 5,70 & 11,28 \\
\hline $\mathrm{MoNi} / \mathrm{MC}$ & 628,72 & 1,02 & 6,46 & 11,86 \\
\hline
\end{tabular}

Table-3 presents surface parameters obtained from SAA analysis result of MS and the catalysts. After impregnation of $\mathrm{Ni}$ and Mo metals, the surface area and pore volume of MC was increased from 404.47 $\mathrm{m}^{2} / \mathrm{g}$ to $560.90 \mathrm{~m}^{2} / \mathrm{g}$ and $628.72 \mathrm{~m}^{2} / \mathrm{g}$ for NiMo/MC and MoNi/MC catalysts, respectively. In preparation of $\mathrm{NiMo} / \mathrm{MC}$ catalysts, the $\mathrm{Ni}$ metal was impregnated previously and followed by Mo metal. The Ni metal was evenly dispersed on the MC surface and it was stacked with Mo metal. However, if the Mo metal was impregnated previously and followed by Ni metal like the NiMo/MC catalyst, the atom of Mo metal would block the pore due to it's a bigger size than the $\mathrm{Ni}$ metal ${ }^{1,6,7}$. This phenomenon made the surface area and pore volume of $\mathrm{NiMo} / \mathrm{MC}$ catalyst be lower than $\mathrm{MoNi} / \mathrm{MC}$ catalyst. The decreasing of pore diameter of the $\mathrm{MC}$ after the impregnation process was caused by the presence of $\mathrm{Ni}$ and Mo metals in the pore of MC. Table-3 also shows acidity test result of the MC and the catalysts. Acidity value of MC synthesized in this work is about $5.42 \mathrm{mmol} / \mathrm{g}$. This acidity value was increased after impregnation of $\mathrm{Ni}$ and Mo metal onto the $\mathrm{MC}$ to $11.28 \mathrm{mmol} / \mathrm{g}$ and $11.86 \mathrm{mmol} / \mathrm{g}$ for $\mathrm{NiMo} / \mathrm{MC}$ and $\mathrm{MoNi} / \mathrm{MC}$ catalysts, respectively. It was caused by the empty d orbitals of $\mathrm{Ni}$ and Mo metal which can bind lone pair electron from the nitrogen 
RASĀYAN J. Chem.

Vol. 11 | No. 4 |1433 - 1440| October - December | 2018

atom of ammonia vapor ${ }^{17,18}$. The high acidity value was desired to increase the activity of the catalyst in hydrocracking of lubricant waste ${ }^{19,20}$.
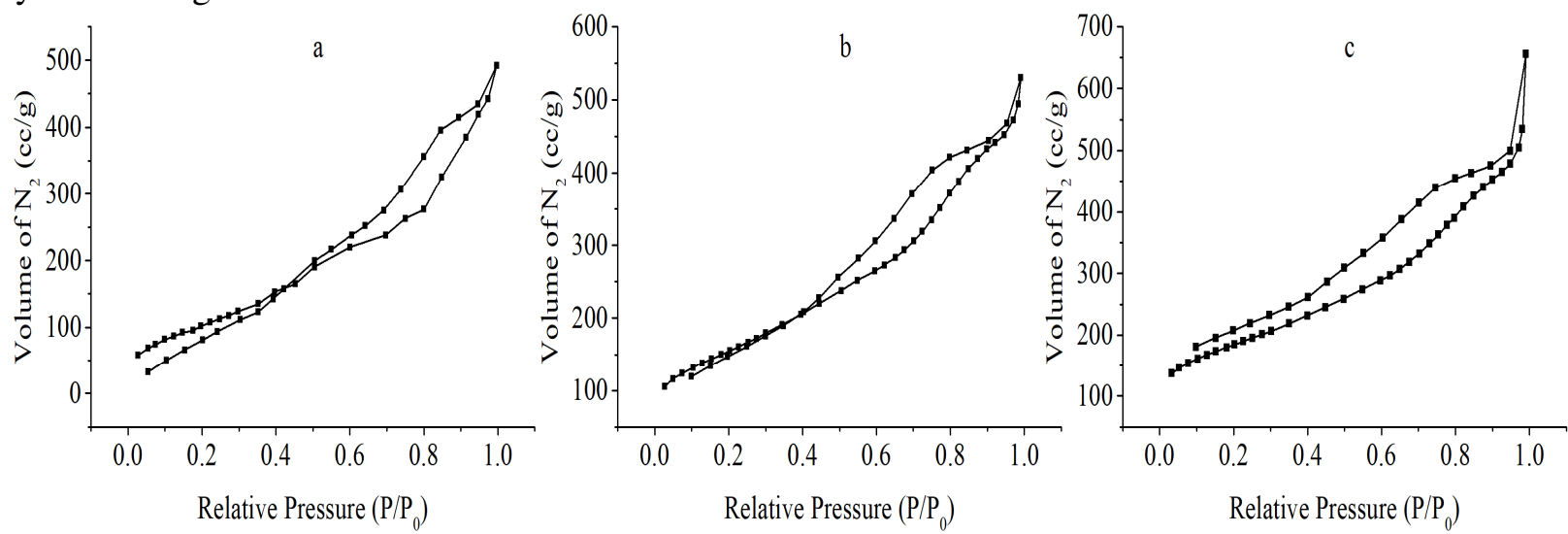

Fig.-5: Adsorption-Desorption Isotherm of $\mathrm{N}_{2}$ on (a) MC, (b) NiMo/MC, dan (c) MoNi/MC

Figure-5 presents adsorption-desorption isotherm of nitrogen gas on the MC and catalysts surface. This adsorption-desorption isotherm is confirmed as type IV as the IUPAC classification with the H3 type of hysteresis loop. Type IV of adsorption isotherm indicates the presence of pore in meso size ${ }^{7}$. The hysteresis loop occurred at $\mathrm{P} / \mathrm{P}_{0}=0.4$ and it means that the multilayer formation was happening at that of relative pressure. The above explanation confirms the formation of mesopore as expected in this work.

\section{Catalysts Activity}

The catalysts activity in the hydrocracking process of lubricant waste is presented in Table- 3 . The thermal hydrocracking was also carried out as a comparison for evaluating the activity of the catalyst. Thermal hydrocracking of lubricant waste produced more gas product than hydrocracking of lubricant waste using $\mathrm{MoNi} / \mathrm{MC}$ with catalyst/feed ratios of $1 / 200,1 / 300$, and 1/400. It was caused by the difference of cracking mechanism between thermal cracking and cracking using catalyst. Thermal hydrocracking occurred through the formation of radical ions. These radical ions break the carbon bond at the $\beta$ position and from new radicals compounds with shorter carbon chain ${ }^{6}$. In another side, the hydrocracking of lubricant waste using the catalysts synthesized in this work occurred through the carbonium mechanism ${ }^{5}$. The Ni and Mo metals in the catalysts provide unpaired electrons in their $\mathrm{d}$ orbitals. These unpaired electrons can dissociate $\mathrm{H}_{2}$ gas, which will be required in the hydrocracking process.

Table-3: Product Distribution of Hydrocracking of Lubricant Waste

\begin{tabular}{c|c|c|c|c}
\hline \multirow{2}{*}{ Catalysts } & \multicolumn{3}{|c|}{ Product Distribution $(\%)$} & \multirow{2}{*}{ The residue } \\
\cline { 2 - 4 } & Liquid & Gas & Coke & $(\%)$ \\
\hline Thermal & 49.91 & 50.09 & 0.00 & 1.22 \\
\hline $\mathrm{MoNi} / \mathrm{MC}(1 / 50)$ & 15.16 & 83.69 & 0.35 & 0.80 \\
\hline $\mathrm{MoNi} / \mathrm{MC}(1 / 100)$ & 47.99 & 50.71 & 0.12 & 1.18 \\
\hline $\mathrm{MoNi} / \mathrm{MC}(1 / 200)$ & 58.36 & 40.38 & 0.07 & 1.19 \\
\hline $\mathrm{MoNi} / \mathrm{MC}(1 / 300)$ & 64.15 & 34.56 & 0.03 & 1.26 \\
\hline $\mathrm{MoNi} / \mathrm{MC}(1 / 400)$ & 62.99 & 35.64 & 0.09 & 1.28 \\
\hline $\mathrm{NiMo} / \mathrm{MC}(1 / 200)$ & 52.89 & 45.71 & 0.07 & 1.33 \\
\hline
\end{tabular}

However, hydrocracking of lubricant waste using MoNi/MC catalyst with catalyst/feed ratios of 1/50 and $1 / 100$ produced a lower liquid product and more gas product than the thermal hydrocracking. This phenomenon may be caused by their higher catalyst/feed ratios. The increasing of the catalyst/feed ratio lead to the increase of total acid sites in the hydrocracking process. This can initiate the secondary cracking process. In the secondary cracking process, the products obtained from the first cracking process were cracked again to be a gas product. The highest amount of liquid product was obtained from hydrocracking of lubricant waste using MoNi/MC catalyst with the catalyst/feed ratio of 1/300. 


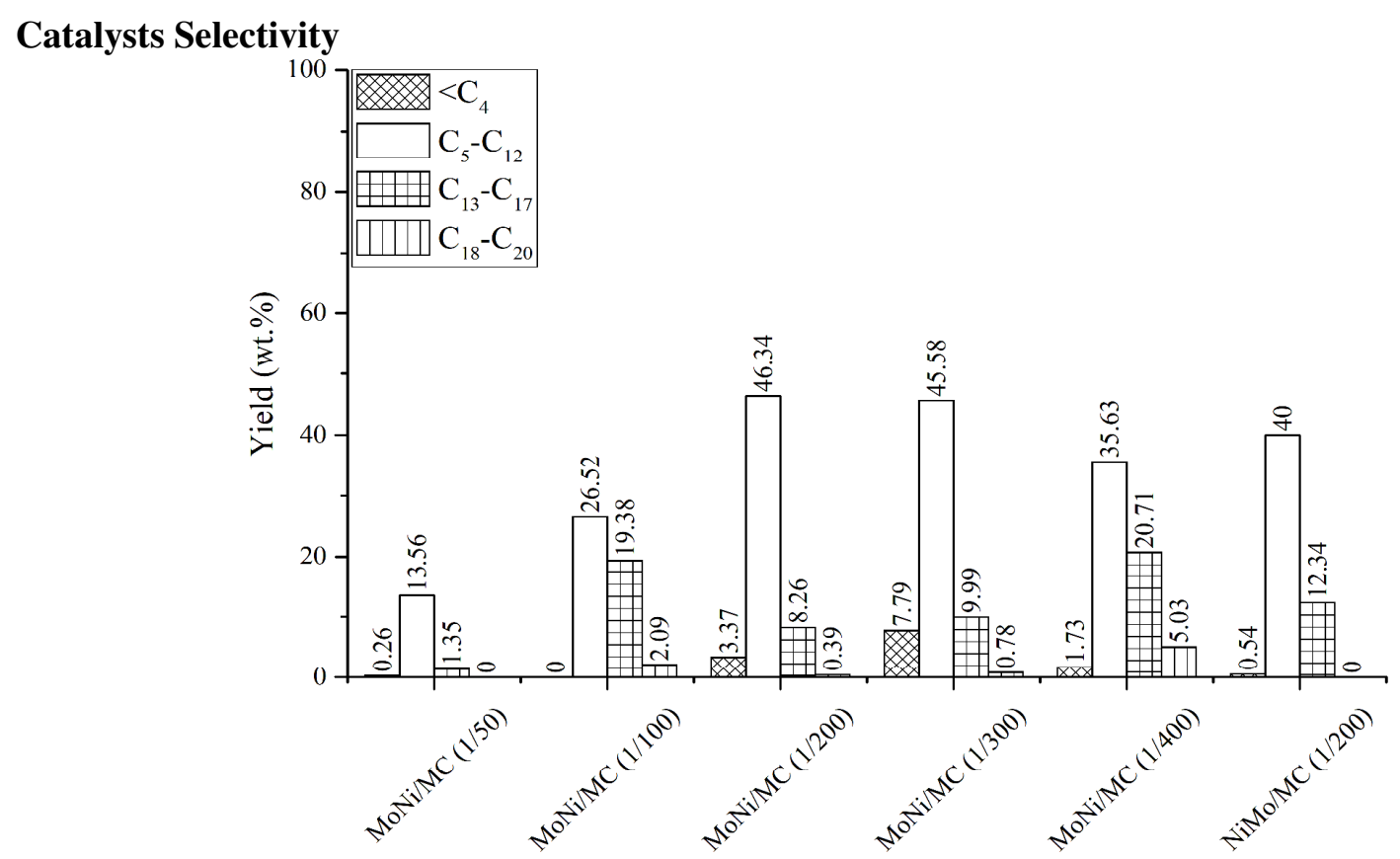

Fig.-6: Product Selectivity From Hydrocracking of Lubricant Waste

Figure-6 shows product selectivity from hydrocracking of lubricant waste using catalysts synthesized in this work. The liquid product obtained from hydrocracking of lubricant waste mainly consists of gasoline fraction $\left(\mathrm{C}_{5}-\mathrm{C}_{12}\right)$. The $\mathrm{MoNi} / \mathrm{MC}$ catalyst produced gasoline up to $47 \mathrm{wt} \%$ toward the amount of lubricant waste used in the hydrocracking process for all of catalyst/feed ratios. A similar result was obtained when the hydrocracking process was carried out using the NiMo/MC catalyst with the catalyst/feed ratio of 1/200. It means that the $\mathrm{MoNi} / \mathrm{MC}$ and $\mathrm{NiMo} / \mathrm{MC}$ catalysts were selective for gasoline production. Moreover, the liquid products also consist of diesel fraction $\left(\mathrm{C}_{13}-\mathrm{C}_{17}\right)$ which can be used as a fuel like the gasoline fraction. The highest amount of gasoline fraction was obtained from hydrocracking of lubricant waste using $\mathrm{MoNi} / \mathrm{MC}$ catalyst with the catalyst/feed ratio of $1 / 200$. This fact leads to the conclusion that the MoNi/MC catalyst has a great ability in production of gasoline if it was used in hydrocracking of lubricant waste with catalyst/feed ratio of $1 / 200$.

\section{CONCLUSION}

Mesoporous Carbon (MC) can be synthesized from bovine bone gelatin and SBA-15 as a template. The MC has a regular pore structure and uniform pore shapes with the specific surface area, pore volume, pore diameter and acidity value of $404.47 \mathrm{~m}^{2} / \mathrm{g}, 0.76 \mathrm{~cm}^{3} / \mathrm{g}, 7.52 \mathrm{~nm}$, and $5.42 \mathrm{mmol} / \mathrm{g}$, respectively. The acidity value of $\mathrm{MC}$ was increased up to two times after impregnation of $\mathrm{Ni}$ and Mo metals. The MoNi/MC catalyst has a greater activity and selectivity for gasoline production when it is used in hydrocracking of lubricant waste with catalyst/feed ratio of $1 / 200$.

\section{ACKNOWLEDGMENT}

The authors thank the Ministry of Research, Technology and Higher Education of Indonesia for financial support of Hibah Penelitian Unggulan Perguruan Tinggi Universitas Gadjah Mada (Contract Number: 916/UN1-P.III/LT/DIT-LIT/2016).

\section{REFERENCES}

1. A. Masykuroh, W. Trisunaryanti, I. I. Falah and Sutarno, Int. J. ChemTech Res., 9, 598(2016).

2. Nurmalasari, W. Trisunaryanti, Sutarno and I. I. Falah, Int. J. ChemTech Res., 9, 607(2016).

3. M. Pongsendana, W. Trisunaryanti, F. W. Artanti, I. I. Falah and Sutarno, Korean J. Chem. Eng., 34, 2591(2017), DOI: 10.1007/s11814-017-0165-3.

4. K. Wijaya, G. Baobalabuana, W. Trisunaryanti and A. Syoufian, Asian J. Chem., 25, 8981(2013), DOI: 10.14233/ajchem.2013.14946.

5. W. Sriningsih, M. G. Saerodji, W. Trisunaryanti, Triyono, R. Armunanto and I. I. Falah, Procedia 
Environ. Sci., 20, 215(2014), DOI: 10.1016/j.proenv.2014.03.028.

6. H. Kusumastuti, W. Trisunaryanti, I. I. Falah and M. F. Marsuki, Rasayan J. Chem., 11, 522(2018), DOI: $10.7324 /$ RJC.2018.1122061.

7. M. F. Marsuki, W. Trisunaryanti, I. I. Falah and K. Wijaya, Orient J Chem, 34, 955(2018), DOI: 10.13005/ojc/340245.

8. K. Wijaya, I. Herlina, W. Trisunaryanti, Nuryono and S. Simbolon, Asian J. Chem., 30, 724(2018), DOI: 10.14233 /ajchem.2018.19770.

9. M. Ulfa, W. Trisunaryanti, I. I. Falah, Sutarno and I. Kartini, Int. J. ChemTech Res., 9, 588(2016).

10. M. Ulfa, W. Trisunaryanti, I. I. Falah and I. Kartini, Indones. J. Chem., 16, 239(2016), DOI: 10.22146/ijc. 1145 .

11. M. Ulfa, W. Trisunaryanti, I. I. Falah and I. Kartini, IOSR J. Appl. Chem., 8, 57(2015).

12. M. Ulfa, W. Trisunaryanti, I. I. Falah, I. Kartini and Sutarno, IOSR J. Appl. Chem., 7, 01(2014).

13. W. Trisunaryanti, I. I. Falah and M. F. Marsuki, In Proceeding of 15th Int. Conf. Environ. Sci. Technol., Greece, pp.00741(2017).

14. W. Trisunaryanti, P. S. Lisna, I. Kartini, Sutarno, I. I. Falah and Triyono, Asian J. Chem., 28, 996(2016), DOI: 10.14233 /ajchem.2016.19561.

15. W. Trisunaryanti, I. I. Fallah, Sutarno, A. Ningtyas, F. Swasdika and D. A. Ratna, Int. J. ChemTech Res., 9, 96(2016).

16. M. J. Rampe, B. Setiaji and W. Trisunaryanti, Indo. J. Chem., 11, 124(2011).

17. I. Salim, W. Trisunaryanti, Triyono and Y. Arryanto, Int. J. ChemTech Res., 9, 492(2016).

18. W. Trisunaryanti, T. Triyono, R. Armunanto, L. P. Hastuti, D. D. Ristiana and R. V. Ginting, Indones. J. Chem., 18, 166(2018), DOI: 10.22146/ijc.26491.

19. U.J. Etim, P. Bai, X. Liu, F. Subhan, R. Ullah and Z. Yan, Microporous Mesoporous Mater., 273, 276(2019), DOI: 10.1016/j.micromeso.2018.07.011.

20. J. Marques, D. Guillaume, I. Merdrignac, D. Espinat and S. Brunet, Appl. Catal. B., 101, 727(2011), DOI: $10.1016 /$ j.apcatb.2010.11.015.

[RJC-3073/2018] 